\title{
Türkiye'nin Yeni Göç Risklerine Karşı Tutumu Üzerine Bir İnceleme: İdlib Örneği
}

\author{
DOI: 10.26466/opus.719410 \\ * \\ Yasin Cam* ${ }^{*}$ Ibrahim Keleş** \\ * Araş. Gör, Osmaniye Korkut Ata Üniversitesi \\ E-Posta: yasincam@osmaniye.edu.tr \\ ORCID: 0000-0001-6009-6233 \\ ** Y.L, Kocaeli Üniversitesi \\ E-Posta: kelesibrahim1334@gmail.com \\ ORCID: 0000-0002-6328-6822
}

\begin{abstract}
Öz
Arap Baharı olarak adlandırılan sürecin etkisiyle Suriye'de 2011 yılında başlayan protestoların zamanla şiddetlenip bir iç çatışmaya dönmesi sebebiyle milyonlarca insan göç etmek zorunda kalmıştır. Türkiye Cumhuriyeti Suriye ile komşu olması sebebiyle bu sürecin başından beri sıkı takipçisi olmuştur. İççatışmalar sebebiyle Suriye'yi terk etmek zorunda kalan insanların 3 milyon 600 bin kadarına 9 yıldır Türkiye ev sahipliği yapmaktadır. Ülkemiz bu süreçte yerinden edilmiş bu insanların eğitim, sağllk, barınma, gıda, güvenlik ve sosyal ihtiyaçlarını karşılamak için büyük çaba göstermiştir. Ülkemiz bu süreçte imkânları çerçevesinde birçok kurumunu harekete geçirmiş ve bu insanların iyi bir şekilde ağırlanması için uğraşmıştır. Ancak Suriye'deki karışıklı̆̆ın gün geçtikçe uzaması ve bir türlü sonuca ulaşmamasına paralel olarak ülkemizde ekonomik ve sosyal bir takım sorunların da meydana gelmesi Türkiye'nin bu alanda yeni politikalar benimsemesine sebep olmuştur. Bu bağlamda, bu çalışmanın amacı Suriye'den kaynaklanan göçler konusunda Türkiye'nin uyguladığı göç ve göçmen kabulü politikalarında bir değiişiklik olup olmadığııın tespitini yapmak, eğer bir değişiklik var ise bu değgişikliklerin sebeplerini incelemektir.
\end{abstract}

Anahtar Kelimeler: Güvenli Bölge, Suriyeli Mülteciler, Göç Politikası, İdlib 


\title{
A Research On The Turkey's Attitude Against New Immigration Risks: The Case of Idlib
}

\begin{abstract}
Millions of people had to migrate due to the protests that started in 2011 in Syria under the influence of the process called the Arab Spring, which intensified over time and turned into an internal conflict. Due to Turkey and Syria are the two neighboring countries, our country has been strict follower since the beginning of this process in Syria. Forced to leave Syria due to internal conflicts remaining 3 million 600 thousand people are hosted in Turkey for 9 years. Our country has made great efforts to provide the educational, health, shelter, food, security and social needs of these displaced people in this process. Our country has mobilized many different institutions in this process and worked to host these people well. However, the fact that the confusion in Syria has been increasing day by day and that it has not reached any result, it has caused Turkey to adopt new policies in this field. In this context, the aim of this study on migration stemming from Syria in the immigration policies implemented by Turkey to make the determination whether a change. if there is a change, so it is to examine the reasons for these changes.
\end{abstract}

Keywords: Safe Zone, Syrian Refugees, Immigration Policies, Idlib 


\section{Giriş}

Suriye Arap Cumhuriyeti'nde 2011 yılı mart ayında başlayan halkın iktidar değişikliği taleplerine yönelik eylemlerinin dozu artarak devam etmiş ve netice olarak Suriye'nin toprak bütünlüğünün tartışıldığı henüz kalıcı bir çözümün bulunamadığı bugünlere gelinmiştir. Bölgede farklı örgütlerinde aktif hale gelmesi ve güçlenmesiyle beraber Suriye' deki iç karışıklıkların bir iç savaşa dönüştüğü görülmüştür. Sürecin iç savaşa dönmesindeki en büyük etmen Esed rejiminin eylemcilere yönelik uyguladığı insanlık dışı muamele, aşırı şiddet ve devamında askerlerin sivillere karşı silah kullanmaktan çekinmemesidir (Yılmaz, 2013, s.2). “Ortaya çıkan istikrarsızlık Suriyelileri güvenli bölgeler arayışı içinde zorunlu göçe maruz bırakmıştır. Bu zorunlu göçler hem ülke içerisindeki değişik bölgelere hem de ülke dışına yönelik olarak gerçekleşmiştir." (Orhan'dan aktaran Ağır ve Sezik, 2015, s. 96).

2011 yılında başlayan çatışmalar sonucunda baskı altında kalan ve Suriye'de bulunması hayati risk teşkil eden insanların çoğunun en baştan beri ilk kaçış yeri Türkiye olmuştur. Ülkemiz sayısal olarak sürekli değişim göstermekle beraber 27 Şubat 2020 tarihi itibariyle 3 milyon 587 bin 266 Suriyeli sığınmacıya ev sahipliği yapmaktadır (Göç İdaresi Genel Müdürlüğü, 2020). Bu büyük göç sürecini yönetmek ve gelen kişilerin kontrolü, adaptasyonu, istihdamı, sağlık ve eğitim hizmetlerini sağlamak için yoğun bir çaba gösteren ülkemiz gerek ekonomik olarak gerekse sosyal olarak belli başlı zararlara uğramıştır. Türkiye Cumhuriyeti Cumhurbaşkanlığı İletişim Başkanı Prof. Dr. Fahrettin Altun'un yapmış olduğu “Suriyeliler için harcadığımız para 40 milyar doları buldu." (Anadolu Ajansı, 2019) açklaması bu sürecin ülkemize yüklediği ekonomik külfeti göstermektedir. Yaklaşık 9 yıldır ülkemizde ağırladığımız Suriyeli insanların uyum, eğitim, sağlık, barınma ve gıda teminine ilişkin birçok politika geliştiren ülkemiz bu insanlar için son derece özen göstermiş ve birçok imkândan faydalanabilmelerini sağlamıştır. Ancak bu sürecin gerek ekonomik gerekse sosyal boyutu ele alındığında ülkemizin daha fazla Suriyeli sığınmacıya kapılarını açamayacağı noktada olması sebebiyle oluşabilecek yeni göç akınlarını önleme ve sığınmacılara yönelik yeni politikalar belirleme ihtiyacı doğmuştur. Ülkemiz 2019 yılında başlayan ekonomik krizi atlatmaya çalışırken daha fazla Suriyeli sığınmacıyı kabul etmesinin doğru olmayacağını da öngörerek Suriyeliler için Suriye toprakları üzerinde bir çözüm üretilmesini ve hem Suriye'den gelecek yeni göçleri engelleme 
hem de ülkemizde bulunan Suriyelilerin kendi topraklarında güvenle yaşamasını sağlamayı amaç edinmiştir.

2019 yılı aralık ayında Rus destekli Esed rejimi askerlerinin İdlib bölgesine yaptığ1 yoğun saldırılar sonucu binlerce insan İdlib şehrinden kaçmaya ve Türkiye sınırına doğru yönelmeye başlamıştır (HaberTürk, 2019). Konum olarak Hatay ilimize komşu olan ve 4 milyon Suriyeli sivilin barındığı bilinen İdlib'den Esed rejimi saldırıları sebebiyle ülkemize gelmesi muhtemel milyonlarca sığınmacının yerinden edilmemesi için Türk Silahlı Kuvvetleri bölgede varlığını göstermiştir (Anadolu Ajansı, 2020). Aynı zamanda Suriye' deki çatışma ortamı ve denetimsizlik bölgedeki PKK/PYD/YPG ve DAEŞ gibi terör örgütlerinin silahlanmasını kolaylaştırmış, bölgede güç kazanmasını sağlamıştır (Ağır ve Sezik, 2015, s.107). Bu bağlamda Türkiye'nin Suriye'ye 911 km sinırı bulunmasından dolayı bu bölgedeki yuvalanan terör örgütlerinden ülkemize gelebilecek terör saldırılarını önlemek için politikalar geliştirmek zorunlu bir hal almıştır. Bu süreçteki en önemli politika ise Suriye'nin kuzeyinde Türkiye sınır hattı boyunca bir güvenli bölge oluşturma planıdır. Cumhurbaşkanı Recep Tayyip Erdoğan'ın Suriye'ye yönelik uluslararası toplantılarda sıklıkla dile getirdiği Suriye'nin kuzeyinde bir güvenli bölge kurma planının bölgede etkili olan diğer devletlerin istenilen düzeyde desteklememesi bölgede Türkiye'yi kendi mücadelesini sürdürmeye itmiştir. Güvenli bölge kavramına bakıldığında ise "Güvenli bölgeler belirli bir nüfusu korumak adına oluşturulan, koruyucu ve caydırıcı bir askeri güç tarafından aktif şekilde güvenli tutulan bölgelerdir." Şeklinde tanımlanmaktadır (Alptekin, 2019, s.8).

Türkiye Cumhuriyeti hem sınırlarında tehdit oluşturan terör unsurlarını temizlemeyi hem de temizlenen bölgelere Suriyeli sığınmacıların dönmesini amaç edinerek 2016 ve 2020 yılları arasında farklı tarihlerde Suriye'nin kuzeyine TSK ve SMO (Suriye Milli Ordusu) ortaklığı ile Firat Kalkanı, Zeytin Dalı, Barış Pınarı ve Bahar Kalkanı isimleri verilen askeri harekâtlar düzenlemiştir. Bu harekâtlar kapsamında Cerablus, Azez, Afrin bölgeleri ile Tel Abyad ve Resulayn arası bölgeler PYD/YPG ve DAEŞ'li teröristlerden temizlenerek TSK ve SMO kontrolüne geçmiştir. Özellikle İdlib'de ise Esed rejiminin sivillere yönelik saldırılarını durdurmak amaçlı olarak bölgede TSK ve SMO varlığın göstermiş ve bu bölgelerin rejim kontrolüne geçmemesi için çaba harcamıştır. Hatay'a komşu olan ve Türkiye ile 130 km sınırı bulanan İdlib 
şehrinde yerel kaynaklara göre 2 milyon 400 bin civarında yerli nüfusun yanında yaklaşık 1 milyon 300 binde iç göç ile bu bölgeye yerleşmiş yaklaşık 4 milyon sivil yaşamaktadır. Bu nüfusun yaklaşık olarak 1 milyonu Hatay-İdlib sınırlarında, sıfır noktası sayılabilecek yaklaşık 200 kampta barınmaktadır (TRTHaber, 2020). Rejim saldırılarından dolayı bu sivillerin doğrudan Türkiye'ye göç etmelerinin kaçınılmaz olması İdlib' in Türkiye açısından önemini ortaya koymaktadır.

Siyasi olarak ise Türkiye'nin içerisinde bulunduğu durum ve göç meselesiyle ilgili gerek siyasi parti liderleri gerekse bakanlar birçok düşünce ve öngörüyle sürece ilişkin yaklaşımlarını ortaya koymuşlardır. Göç süreci ve İdlib meselesine ilişkin birçok farklı öneri birçok farklı onay ya da red bu süreçte ortaya çıkmıştır. Türkiye'nin göç yönetimine ilişkin olarak bazı yeni politikaların doğduğu ve bu sürecin devamı olarak 2016 yılından sonra Suriye'de askeri olarak harekete geçtiği de görülmüştür.

\section{Yöntem}

Bu çalışmada nitel araştırma yöntemlerinin önemli bir veri toplama aracı olan doküman ve söylem inceleme tekniğinden yararlanılmıştır. Konuya ilişkin olarak farklı doküman ve kaynaklar incelenmiş aynı zamanda Türkiye'de gerek Cumhurbaşkanlığı gerekse bakan ve diğer bürokratların ülkemizde mevcut sığınmacılar, olası yeni göç dalgası ve İdlib meselesi ile ilgili söylemleri incelenmiştir. İlgili konular hakkında bugüne kadar izlenen politikalar, olası yeni göç dalgasının sebep olacağı sorunlar ve İdlib meselesinde izlenen yol hakkında düşünceler çalışmanın içeriğini oluşturmuştur. Özellikle Suriye'de bir güvenli bölge oluşturma fikrinin ve bu çerçevede Türkiye'nin uyguladığ Suriye' nin kuzeyini kapsayan gerek askeri operasyonlar gerekse uluslararası politik toplantıların önemi ve sonuçları incelenmiş, konuya ilişkin web siteleri ve çeşitli makaleler taranmış olup hem doküman hem de söylem incelemesi yapılmıştır.

\section{Bulgular}

Türkiye'nin 911 km uzunluğunda sınır hattına sahip olduğu komşu ülkesi Suriye, 2011 yılında ortaya çıkan ve temelinde Arap Baharı olarak adlandırılan sürecin yattığı eylemlerden en çok etkilenen ülke olmuştur. Süreç eylemler ve protestoların büyüyüp ülkeyi sarsan bölgesel iç çatışmalar bütününe 
dönmüştür. Özellikle ülkenin doğu ve kuzey kesimleri YPG/PYD ve DAEŞ başta olmak üzere birçok terör örgütlerinin hakimiyet alanına dönmüştür. Suriye'deki silahlı çatışmalardan ve etnik ayrılıkçı baskılardan etkilenen ve hayatı risk altında bulunan insanlar başta Türkiye olmak üzere komşu ülkelere göç etmişlerdir. Sayısal olarak sık sık değişiklik göstermekle beraber Türkiye 2020 Mart ayı itibariyle 3 milyon 589 bin 289 Suriyeli insana ev sahipliği yapmaktadır. Bu süreçte sayısal olarak zaman zaman artıslar ve azalışlarda yaşanmaktadır (Göç İdaresi Genel Müdürlüğü, 2020).

Ülkemizde hükümet süreç sonrası Suriyeli insanlara uyguladığı açık kapı politikası ve Suriye rejimi ile ilişkilerde gelinen noktanın çeşitli riskler doğurduğunu fakat din kardeşliği ve tarihsel bağlarımızın bulunması aynı zamanda akrabalıkların olması sebebiyle Suriyeli insanlara sahip çıkmamız gerekliliğini vurgulamış, bunun Müslümanlığın ve insanlığın gereği olduğu konusunda birçok çeşitli açıklamalar yapmıştır (Koyuncu, 2015, s. 460). Sığınmacılara yönelik politikalarını evrensel hukukun yanı sıra inanç gereği İslami kaidelerle de güçlendiren AK Parti, halkı Suriye'den gelen göç akınlarına karşı kültürümüz gereği misafirperverlik göstermeye ve Müslüman Suriye halkına yardımda bulunma çağrısı yapmıştır. Suriye'de toplumun çok inançlı ve farklı etnik kimliklere sahip olduğuna vurgu yapan Recep Tayyip Erdoğan mazlum insanların dinini, etnik kökenini, mezhebini, rengini, sınıfını gözetmeksizin yardım eli uzattıklarını sıklıkla dile getirmiştir (Devran ve Özcan, 2016, s.43). Recep Tayyip Erdoğan 2014 yılında Islahiye çadır kentinde Suriyelilere yönelik yaptı̆̆ konuşmada Türkiye'nin Suriyeli sığınmacılara kucak açtığını vurgulayarak "Bizler Türkiye olarak yaklaşık dört yıldır sizleri burada misafir etmenin memnuniyeti, sevinci ve hakl gururu içerisindeyiz. Sizler muhacir oldunuz. Mecburiyet içerisinde yurtlarnızı terk ettiniz. Bizler de ensar olduk sizin için tüm imkânlarımızı seferber ettik. Kim ne derse desin sizler bize asla yük değilsiniz." İfadelerini kullanmıştır (Hürriyet, 2014). Türkiye'nin Suriye'den gelen göç dalgasına karşı göstermiş olduğu insani hassasiyet ve süreci yönetme başarısı diğer ülkelerle kıyas yapılamayacak oranda başarılı olduğu söylenebilir. Ancak bu sürecin dokuzuncu yılına girmesine karşın Suriye'de hala bir çözüm üretilememiş olması Türkiye' yi sosyal ve politik açıdan yormuştur.

Bu bağlamda göç sorununa bir çözüm olarak güvenli bölge oluşturma fikri gündeme gelmiş, özellikle ülkemiz tarafından sıklıkla dile getirilmiştir. Türkiye güvenli bölge ve tampon bölge kavramlarını sıklıkla dile getirerek 
güvenli bölgenin Suriye'nin kuzeyinde bir ihtiyaç olduğu doğrultusunda birçok beyanda bulunmuştur. 2012 yılında Türkiye tarafından yapılan bir açıklamada Türkiye'ye Suriye'den geçişlerin yoğunlaşacağ 1 ve bu geçişlerin PKK için avantaj olabileceği, PKK'nın sızma girişimlerinde bulunabileceği kaygısı dile getirilmiş ve "Gelişmelere göre tampon bölge konusu da değerlendirilebilir" ifadesi kullanılmıştır (Alptekin, 2019, s.10). 2012 yılında ilk kez güvenli bölgeyi dillendirmeye başlayan Erdoğan, 2014 yılında ABD'nin o dönemki başkan yardımcısı Joe Biden ile görüşmüş ancak beklenilen sonuca erişilememiştir. Türkiye'nin en baştan beri bölgedeki amacı Suriye'nin kuzeyinde barınan YPG/PYD, DAEŞ terör örgütünü engellemek ve o bölgede kurulacak güvenli bölgeye Suriyeli sığınmacıların yerleşmesini sağlamaktır (Fırat, 2019). Türkiye istediği güvenli bölgeyi Rusya ve ABD ile herhangi bir gerginlik oluşmadan kurabilecek ve sürdürebilecek tek ülke olduğunu savunmaktadır. Planlanan ilgili bölgede YPG/PYD ve DAEŞ terör örgütleri saf dışı bırakılırken bölgede yerel katılım ön planda olacaktır (Alptekin, 2019, s.18). Suriye'nin kuzeyinde Türkiye sınırından başlayarak Suriye'de bulunan M4 karayoluna kadar ulaşan $32 \mathrm{~km}$ derinlikte bir güvenli bölgenin oluşturulması oradaki terörist grupların temizlenmesi ve bölgenin iyileştirilmesinin ardından Suriye'den Türkiye'ye olan göç hareketlerinin çözümü için önemli bir proje olacaktır (Alptekin, 2019, s.20).

2011 yılından beri süregelen ve insanlar için çok acı bilançolara sebep olan Suriye iç savaşında Esed rejiminin son dönemlerde sahada elde ettiği kazanımların ardından İdlib şehri rejim muhaliflerinin son kalesi durumuna gelmiş ve büyük önem kazanmıştır (Acun \& Salaymeh, 2018, s. 8). İdlib'in bir dönem Rus destekli Esed güçlerinin eline geçtikten sonra muhaliflerin güç kazanıp İdlib'i geri almalarıla beraber rejim kuvvetlerinin bölgeden çekilmesinin ardından İdlib kent merkezine göç hareketi artmaya başlamıştır. Özellikle Esed rejiminin yürürlüğe koyduğu tahliye anlaşmalariyla beraber İdlib kent merkezi başta olmak üzere bölge nüfusundaki artış daha da hızlanmıştır. Suriye'nin farklı bölgelerinden tehcir edilen muhalif kesim ve ailelerinin İdlib'e nakli gerçekleştirilmiştir (Acun ve Salaymeh, 2018, s. 18). Bu bağlamda İdlib nüfusundaki bu önemli artış ve İdlib'e yönelik saldırıların bu nüfusu Türkiye'ye itecek olması ülkemizin Suriye'deki süreç açısından daha sert tavır almasını tetiklemiştir. Türkiye açısından İdlib'in korunması; yeni sığınmacı akınlarından korunmak, Zeytin Dalı Harekâtı, Fırat Kalkanı Harekâtı ve Barış Pınarı Harekâtı bölgelerindeki nüfuzu kaybetmemek, 
YPG/PYD başta olmak üzere diğer terör örgütleriyle mücadeleyi sürdürmek aynı zamanda Suriye'nin geleceğine yönelik görüşmelerde masanın dışında kalmamak açısından büyük öneme sahiptir (Acun \& Salaymeh, 2018, s. 23).

İdlib meselesi her ne kadar sadece ülkemiz için bir sorun olarak gösterilse de aslında yalnızca Türkiye'nin ulusal bir sorunu değil aynı zamanda Avrupa ülkeleri başta olmak üzere uluslararası bir sorun teşkil etmektedir. Prof. Dr. Mesut Hakkı Caşın, TRT Haber'e verdiği bir mülakatta İdlib şehrinin önemine ilişkin şu sözleri dile getirmiştir:

"İdlib meselesi sadece Türkiye'nin meselesi değil Birleşmiş Milletler, uluslararası toplum ve Avrupa Birliği'nin de meselesidir. Neden? BM Genel Sekreterinin açıklamasına göre Suriye rejiminin saldırlarından dolayı 300 bin kişinin sınıra doğru geldiğini görüuyoruz. Buradan gelecek göç dalgasını Türkiye karşılayamaz. Buradan gelenler ya denizden ya karadan Avrupa'ya geçecek bu da Avrupa'nın güvenliğinin ve stratejik çıkarın zora sokar" (TRT Haber, 2020).

$\mathrm{Bu}$ açıklamalar göz önüne alındığında, $\mathrm{AB}^{\prime}$ ye uzak gibi görünen mülteci göçü ve İdlib sorununun aslında Avrupa açısından olumsuz sonuçlara gebe olduğu öngörülen bir gerçektir. Avrupa için olumsuzluk yaratabilecek bu süreçte, $A B^{\prime}$ nin Türkiye'ye sığınmacılar konusunda verdiği sözleri tutmaması aynı zamanda İdlib meselesinde Türkiye'nin yanında olmaması sebebiyle Türkiye sığınmacı yükünü artık tek başına kaldıramayacağını bildirmiş, bu konuda yalnızlaşmasından dolayı sınırlarında denetimleri kaldıracağını ve kendi rızasıyla gitmek isteyen sığınmacı ve göçmenlere her hangi bir durdurma politikası uygulamayacağını bu bağlamda sınır kapıları açtı̆̆ını 28.02.2020 tarihinde bildirilmiştir (Anadolu Ajansı, 2020).

Suriye'den kaçışın başladığı ilk yıllardan itibaren Avrupa ülkelerinin mültecileri kabule yönelik olumsuz tavrı ve Ege Denizinden Avrupa'ya geçmek için kaçak yollara başvuran birçok insanın teknelerinin batması sonucu hayatlarını kaybetmesini takiben 18 Mart 2016 tarihinde Türkiye, AB ile geri kabul anlaşması imzalamıştır. Bu anlaşma gereği,

- Türkiye'ye vize serbestisi,

- Gümrük Birliği anlaşmasında revizyon,

- Üyelik müzakerelerinde bazı fasılların açılması,

- Sinir güvenliğine destek sözü,

- 6 milyar Euro para desteği sunulması kararlaştırılmıştır.

Tüm bu maddeler karşılığında ise Avrupa'ya geçen mültecilerin Türkiye'ye iadesi kararlaştırılmıştır. Anlaşma gereği Avrupa'dan Türkiye'ye 
iade edilecek olan yasadışı Avrupa'ya geçmiş her bir Suriyeli için Türkiye'deki kayıt altında olan bir Suriyeli Avrupa'ya gönderilecekti. Ancak AB bu süreçte verdiği sözlerin çok az bir kısmını yerine getirmiş ve bu süreçte Türkiye yalnız kalmıştır (Eliaçık, 2020). Hem maddi hem de manevi destek sözlerinin AB tarafından yerine getirilmemesinden dolayı 2019 yılı Temmuz ayında Dışişleri Bakanı Mevlüt Çavuşoğlu AB ile yapılan Geri Kabul Anlaşmasının askıya alındığını duyurmuştur.

Türkiye, Suriye'deki kaos sürecinin başlangıcından bugüne ülkemize gelen Suriyelilerin ihtiyaçlarını karşılamak için çeşitli birçok harcamalar yapmıştır. Bu harcamaların başında ise farklı illerde kurulan geçici barınma merkezleri gelmektedir. "Türkiye hükümetinin Türkiye ile Suriye sınırında kurduğu 25 kampta Ağustos 2015'ten beri Suriyeli mülteci sayısı 262.134'lere ulaşmıştır. Bu kampların tamamı Suriyeli mültecilerle dolmaktadır. Mülteci nüfusun $\% 85$ 'i şehir mültecileri olarak ülkenin dört bir yanındaki il ve ilçelere dağıtılmış durumdadır." (Öztürk \& Çoltu, 2018, s. 191). 2020 Mart ayı itibariyle ise ülkemizde 5 ilde sadece 7 geçici barınma merkezi kalmış ve çoğu barınma merkezleri (kamplar) kapatılmıştır (Göç İdaresi Genel Müdürlüğü, 2020). Bunun dışında ülkemiz yine Suriyelilere yönelik eğitim, sağlık, gıda, nakdi yardım gibi pek çok alanda temel insani ihtiyaçları karşılamak adına ciddi harcamalarda bulunmuştur.

2017 yılı aralık ayında dönemin başbakan yardımcısı Recep Akdağ' ın yaptığı açıklamalara göre Türkiye2011 yılından 2017 yılı sonunda kadarki süreçte Suriyelilere yönelik 30 milyar 285 milyon 573 bin dolar harcanmıştır (Anadolu Ajansi, 2017).

Tablo 1. Türkiye'nin Suriyeliler İçin Yapmış Olduğu Harcamalar (Anadolu Ajansı)

\begin{tabular}{lc}
\hline Harcama Kalemleri & Harcama Miktarı (TL) \\
\hline AFAD & 5 milyar 586 milyon 594 bin \\
Türk Kızılayı ve Çeşitli Vakıflar & 2 milyar 58 milyon 122 bin \\
\hline Göç İdaresi Genel Müdürlüğ̈ & 780 milyon 807 bin \\
Güvenlik ve Kamu Hizmetleri & 9 milyar 228 milyon 707 bin \\
Sağlık Hizmetleri & 16 milyar 30 milyon 111 bin \\
Eğitim Hizmetleri & 15 milyar 489 milyon 968 bin \\
Belediyecilik Hizmetleri & 17 milyon 527 milyon 481 bin \\
Furat Kalkanı Bölgesi & 1 milyar 630 milyon 457 bin \\
Sıfır Noktası İnsani Yardımı & 2 milyar 228 milyon 775 bin \\
Belediye Kampanyaları & 312 milyon 92 bin \\
Kamp Amortisman Maliyetleri & 1 milyar 505 milyon 386 bin \\
Diğer STK Harcamaları & 852 milyon 600 bin \\
Dağıtılan Yardım Giderleri & 11 milyar 649 bin 434 bin \\
TOPLAM & 84 milyar 880 milyon \\
\hline
\end{tabular}


Tablo 1'de görüldüğü üzere en çok harcama tutarı olan alanların devletinde önem ve öncelik verdiği alanlar olan eğitim, sağlık ve yardım giderleri olduğu görülmektedir. Bu harcamalar devam eden süreç gereği 2018 ve 2019 yıllarında da devam etmiş ve 2019 yılsonu yapılan açıklamalarda toplam harcamaların dolar bazında 40 milyarı bulduğu başta Cumhurbaşkanı olmak üzere diğer yetkili organlarca bildirilmiştir. Türkiye'nin çoğu Avrupa ülkesine göre gayri safi milli hasılasının düşük olması ve bütçesinin açı verdiği düşünüldügünde Suriyeliler için yaptığı bu harcamaların insan hak ve onuruna ne kadar önem verdiğini ve süreci ciddiye aldığının bir göstergesidir.

Suriye'deki insani dram ve siyasi krizin çözümüne yönelik 2012 yılından bugüne pek çok siyasi toplantı ve görüşmeler yapılmış ve birçoğunda Türkiye de masada bulunmuştur. Ancak Suriye'de sahada olan ülkelerin elde ettikleri nüfuzlarını kaybetmek istememeleri ve bu ülke ve aktörlerin çözüme yönelik esnek davranmamaları sebebiyle görüşmeler ya sonuçsuz kalmış ya da kısa vadeli ve kısmi çözümlerle sonuçlanmıştır.

Tablo 2: Suriye'deki Karışıklığa Yönelik Yapılan Görüşmeler (stratejikortak.com)

\begin{tabular}{|c|c|c|c|c|}
\hline Tarih & Görüşme & Suriye'deki Durum & Taraflar & Sonuç \\
\hline 30 Haziran 2012 & Cenevre 1 & $\begin{array}{l}10.000 \text { Ölü ve } 112.000 \\
\text { Sığınmacı }\end{array}$ & $\begin{array}{l}\text { BMGK } 5 \text { daimî üyesi, AB, Arap } \\
\text { Birliği, Türkiye, Katar, Kuveyt ve } \\
\text { Irak }\end{array}$ & Başarısız \\
\hline $\begin{array}{l}22 \text { Ocak / } \\
16 \text { Şubat } 2014\end{array}$ & Cenevre 2 & $\begin{array}{l}135.000 \text { Ölü } \\
\text { ve3.000.000 Sığınmacı }\end{array}$ & $\begin{array}{l}\text { Suriyeli Muhalif ve Devrimci Güç- } \\
\text { ler Koalisyonu, Suriye rejimi ve } \\
\text { Türkiye dahil } 40^{\prime} \text { a yakn ülke (İran } \\
\text { Hariç) }\end{array}$ & Başarısız \\
\hline 01 Şubat 2016 & Cenevre 3 & $\begin{array}{l}\text { 250.000 Ölü, } 6.000 .000 \\
\text { Sığınmacl, } \quad 7.600 .000 \\
\text { Ülke İçi Yer } \\
\text { Değiştiren }\end{array}$ & $\begin{array}{l}\text { Suriye Rejimi, Yüksek Müzakere } \\
\text { Komisyonu (Muhalifler), BM Su- } \\
\text { riye Özel Temsilcisi }\end{array}$ & Başarısız \\
\hline 20 Aralık 2016 & Moskova & $\begin{array}{l}\text { Kısmi Ateşkes } \\
\text { Sağlandı }\end{array}$ & Türkiye, Rusya ve İran & Başarılı \\
\hline 27 Ocak 2017 & 1. Astana & $\begin{array}{l}\text { Ateşkes devam } \\
\text { ediyor. }\end{array}$ & Türkiye, Rusya ve İran & Başarılı \\
\hline 15 Şubat 2017 & 2. Astana & $\begin{array}{l}\text { Ateşkes sekteye } \\
\text { uğradı. }\end{array}$ & $\begin{array}{l}\text { Türkiye, Rusya, İran, Rejim ve } \\
\text { Muhalifler }\end{array}$ & $\begin{array}{l}\text { Kısmen } \\
\text { Başarılı }\end{array}$ \\
\hline 23 Şubat 2017 & Cenevre 4 & $\begin{array}{l}\text { Rejim tarafından } \\
\text { ateşkes ihlalleri } \\
\text { devam ediyor. }\end{array}$ & $\begin{array}{l}\text { Türkiye, Rusya, Rejim ve Muhalif- } \\
\text { ler }\end{array}$ & $\begin{array}{l}\text { Kısmen } \\
\text { Başarılı }\end{array}$ \\
\hline 14 Mart 2017 & 3. Astana & $\begin{array}{l}\text { Rejim tarafından ateş- } \\
\text { kes ihlal ediliyor. }\end{array}$ & $\begin{array}{l}\text { Türkiye, Rusya, İran ve Temsilci- } \\
\text { ler (Ürdün, } A B D \text { ve } A B)\end{array}$ & $\begin{array}{l}\text { Kısmen } \\
\text { Başarılı }\end{array}$ \\
\hline 22 Mart 2017 & Cenevre 5 & $\begin{array}{l}\text { Çatışmalar } \\
\text { devam ediyor. }\end{array}$ & Rejim ve Muhalifler & $\begin{array}{l}\text { Kısmen } \\
\text { Başarılı }\end{array}$ \\
\hline 3-4 Mayıs 2017 & 4. Astana & $\begin{array}{l}\text { Çatışmalar } \\
\text { devam ediyor. }\end{array}$ & Türkiye, Rusya ve İran & $\begin{array}{l}\text { Kısmen } \\
\text { Başarılı }\end{array}$ \\
\hline
\end{tabular}




\begin{tabular}{|c|c|c|c|c|}
\hline 20 Mayıs 2017 & Cenevre 6 & $\begin{array}{l}\text { Çatışmalar } \\
\text { devam ediyor. }\end{array}$ & Rejim ve Muhalifler & $\begin{array}{l}\text { Kismen } \\
\text { Başarılı }\end{array}$ \\
\hline $\begin{array}{lr}4-5 & \text { Temmuz } \\
2017 & \\
\end{array}$ & 5. Astana & $\begin{array}{l}\text { Çatışmalar } \\
\text { devam ediyor. }\end{array}$ & $\begin{array}{l}\text { Türkiye, Rusya, İran, Ürdün, } \\
\text { ABD, Rejim ve Muhalifler }\end{array}$ & $\begin{array}{l}\text { Kısmen } \\
\text { Başarılı }\end{array}$ \\
\hline 10 Temmuz 2017 & Cenevre 7 & $\begin{array}{l}\text { Çatışmalar } \\
\text { devam ediyor. }\end{array}$ & BM, Rejim ve Muhalifler & $\begin{array}{l}\text { Kısmen } \\
\text { Başarılı }\end{array}$ \\
\hline 14 Eylül 2017 & 6. Astana & $\begin{array}{l}\text { Çatışmalar } \\
\text { devam ediyor. }\end{array}$ & $\begin{array}{l}\text { Türkiye, Rusya, İran, ABD, BM, } \\
\text { Ürdün, Rejim ve Muhalifler }\end{array}$ & $\begin{array}{l}\text { Kısmen } \\
\text { Başarılı }\end{array}$ \\
\hline 30 Ekim 2017 & 7. Astana & $\begin{array}{l}\text { Çatışmalar } \\
\text { devam ediyor. }\end{array}$ & Türkiye, Rusya, İran & $\begin{array}{l}\text { Kısmen } \\
\text { Başarılı }\end{array}$ \\
\hline 22 Kasım 2017 & 1. Soçi & $\begin{array}{l}\text { Çatışmalar } \\
\text { devam ediyor. }\end{array}$ & Türkiye, Rusya, İran & $\begin{array}{l}\text { Kısmen } \\
\text { Başarılı }\end{array}$ \\
\hline 28 Kasım 2017 & Cenevre 8 & $\begin{array}{l}\text { Çatışmalar } \\
\text { devam ediyor. }\end{array}$ & BM, Rejim ve Muhalifler & Başarısız \\
\hline 25-26 Ocak 2018 & Cenevre 9 & $\begin{array}{l}\text { Çatışmalar } \\
\text { devam ediyor. }\end{array}$ & $\begin{array}{l}\text { BM, Rejim, Muhalifler, Türkiye, } \\
\text { Rusya, İran }\end{array}$ & Başarısız \\
\hline 30 Ocak 2018 & 2. Soçi & $\begin{array}{l}\text { Çatışmalar } \\
\text { devam ediyor. }\end{array}$ & Türkiye, Rusya, İran & $\begin{array}{l}\text { Kısmen } \\
\text { Başarılı }\end{array}$ \\
\hline
\end{tabular}

Türkiye, Suriye sürecine büyük önem vermiş, görüşmelerin çoğunda yer almıştır. Ancak yapılan bölgesel ateşkeslere uyulmaması “'Rejimin yoğun saldırılarını sürdürmesi ve siyasi geçiş meselesini görüşmeyi reddetmesi nedeniyle, Cenevre görüşmeleri, 25-26 Ocak 2018 tarihlerinde gerçekleştirilen dokuzuncu turun ardından kesilmiştir." (T.C. Dışişleri Bakanlığı, 2020). Saldırılarına devam eden ve İdlib bölgesine de zaman zaman saldırılarda bulunan Rusya'nın desteklediği Esed rejimi, 2019 sonlarına doğru saldırılarını arttırmış ve İdlib bölgesinden halkın kaçışına sebep olmuştur. Buradaki nüfusun yerinden edilmesi ve göç için hareketlendirilmesi Türkiye'nin istemediği yeni bir Suriye kaynaklı göçü açığa çıarmaktadır. Erdoğan ve Putin 2019 yılı içerisinde 6 kez olmak üzere 15 Temmuz 2016 tarihindeki darbe girişiminin ardından 2020 yılına kadarki sürede 24'ü yüz yüze, 45'i telefon aracılığıyla olmak üzere toplam 69 kez görüşmüşlerdir. Bu görüşmelerin büyük çoğunluğu ise Suriye'deki durum üzerine olmuştur (Köker, 2019). 27 Şubat 2020 tarihinde İdlib'de bulunan askerlerimize yapılan saldırının ardından bir kez daha yüz yüze görüşen Erdoğan ve Putin, İdlib bölgesinde ateşkes ve ortak devriye üzerine anlaşmışlardır. Tüm bu görüşmelerin sonuçları incelendiğinde kısa vadeli ve yüzeysel çözümlerin açığa çıktığı görülmektedir. Türkiye haricindeki tarafların (Rusya, ABD, Esed Rejimi, İran) bir türlü kesin çözüme ulaşacak tavır içerisinde olmaması ve elde edilen kazanımlardan kimsenin vazgeçmek istememesi Suriye'deki sürecin çözümünün önündeki en büyük engeldir. 
Suriye'de çözüm için yürütülen Astana görüşmelerinin garantör ülkeleri olan Türkiye, Rusya ve İran 4-5 Mayıs 2017 tarihlerinde yapılan görüşmede yoğun çatışmaların ve bombardımanların yaşandığ 1 İdlib ve civarındaki batı Halep kırsalı, Lazkiye kırsalı ve kuzey Hama kırsalını kapsayan alanı Gerginliği Azaltma Bölgesi ilan etmişlerdir (Anadolu Ajansı, 2020). Ancak verilen bu karar da kesin bir çözüm olmamış 2019 yılını takiben saldırı ve çatışmalar sürmüştür. Türkiye ve Rusya'nın 17 Eylül 2018 tarihinde Soçi'de yaptığı görüşmede İdlib bölgesinde silahtan arındırılmış bölge mutabakatına varmasına rağmen, çatışmaların devam etmesi ve rejimin sahadaki saldırgan tavrı ile ele geçirdiği İdlib' in güney kesimleriyle Hama'nın kuzeyinde ele geçirdiği birçok yerleşim alanında yaklaşık 1 milyon insan yerinden edilmiştir. Siviller Türkiye sınırı ve Türkiye'nin terör örgütlerinden temizlediği Fırat Kalkanı ve Zeytin Dalı Harekâtı bölgelerine yönelmişlerdir (Anadolu Ajansı, 2020). Burada en önemli nokta Türkiye'nin yaptığı operasyonlar neticesinde güven ve huzura kavuşan yerlerin saldırılardan kaçan Suriyeli insanlara yurt olması ve insanların bu bölgeleri tercih etmesidir. Öyle ki, Türkiye operasyonlar düzenleyerek güvenli hale getirdiği Cerablus, Afrin, El-Bab bölgelerine birçok insani yardım malzemesi göndermiş ve sağlık merkezleri, eğitim merkezleri inşa etmiştir. Örneğin, Cerablus'ta enkaz kaldırma, asfalt ve kilit taşı döşeme faaliyetleri yürütülmüş, sahra hastaneleri ve sağlık merkezleri kurulmuştur. Yine Cerablus'ta 114 okul 1 halk eğitim merkezi ve Gaziantep Üniversitesi'ne bağlı MYO kurulmuş, gençlere yönelik olarak futbol ve basketbol sahaları, gençlik merkezleri, çocuk oyun alanları inşa edilmiştir. Zarar gören sokak, ev ve camiler restore edilmiş, tarımsal destekler sağlanmış ardından PTT, yerel meclis binası, ziraat ofisleri, adalet sarayı, yetimhaneler, fırınlar kurulmuştur. Su ve elektrik sorunlarını çözmek için su kuyuları açılmış, jeneratörler kurulmuştur (Aslan, 2019). Yapılan tüm bu hizmetler neticesinde Türkiye oluşturduğu güvenli bölgelerde Suriyeli insanların güven içinde yaşamasını ve bölgenin normalleşmesine aynı zamanda bölgede yaşayan insanların yerinden edilmemesine, orada tutunmalarına imkân sağlamıştır.

Türkiye Esad rejimi ve destekçilerinin İdlib'e saldırı düzenlemesi ve hâkimiyetine geçirmeleri ile Suriye'de masanın dışında kalabileceğinin farkındadır. Bu durumun gerçekleşmesi ülkemizi ciddi bir sığınmacı göçüne uğraması da ülkemiz açısından bir tehdit oluşturmaktadır. Bundan dolayı Tür- 
kiye kendi askeri gücüyle İdlib'deki hâkimiyetini arttırmak öte yandan bölgedeki yerel unsurlar üzerindeki nüfuzunu arttırmayı amaçlamaktadır (Özdemir, 2017).

Cumhurbaşkanı Erdoğan 22 Aralık 2019 tarihinde katıldığı bir ödül töreninde "Türkiye, Suriye kaynaklı yeni bir gö̈ç dalgasını kaldıramaz. 4 milyon insanın İdib'teki son katliamlarda sebebiyle bu bölgede tekrar ciddi bir hareketlilik oluştu. Bombardımandan kaçan 80 binin üzerinde İdlibli kardeşimiz ülkemiz sınırına doğru göçe başladı. Böyle bir durumda Türkiye bu göç yükünü tek başına taşımayacaktır" ifadelerini kullanmıştır (İHA, 2019).

Türkiye'nin Suriye kaynaklı yeni göç dalgalarına maruz kalma ihtimaline karşılık Cumhurbaşkanı yardımcısı Fuat Oktay 6 Eylül 2019 tarihinde yaptığı açıklamada Avrupa ülkelerini kastederek "Türkiye onlarm göçmen deposu değildir. Oluşturdukları krizlerin de faturasın ödeyecek ülke değildir. Nasıl olsa yeni göç akımı dalgası başlarsa Türkiye bunu göğ̈̈sleyecektir yaklaşımı ve rahatlığı, kesinlikle yanlış bir rahatlık ve yaklaşımdır." ifadelerini kullanmıştır (Aktan, 2019).

İçişleri Bakanı Süleyman Soylu Avrupa ülkelerinin göçmenler konusundaki tutumuna ilişkin olarak "Tepkileri, sadece bize dönüp, 'aman bunlar bırakmayın, bunlarm bize gelmesini engelleyin' çerçevesinde oldu. Kusura bakmasınlar, bunu o bölgede savaşa sessiz kaldiklarmnda düşünselerdi. Yine kusura bakmasinlar, acımasızca terör örgütlerine silah gönderdiklerinde bunu düşünselerdi." ifadelerini kullanmıştır (Boztepe, 2020).

Milli Savunma Bakanı Hulusi Akar ise göç ve İdlib sürecine ilişkin "Biz oradaki sorumluluklarımız neyse onu yapıyoruz. Yeni bir insani trajedi yaşanmaması için 3,5-4 milyon insanın daha fazla ezaya, cefaya, katliama maruz kalmaması için Türkiye Cumhuriyeti olarak elimizden gelen her şeyi yaptık, yapmaya devam edeceğiz. Böylece yeni bir göç dalgasinin, Türkiye'ye, Türkiye'den Avrupa'ya hatta Amerika'ya kadar uzanacak bir trajedinin de önlenmesi için gayret gösteriyoruz." ifadelerini kullanmıştır (CNNTürk, 2019).

Türkiye'nin Suriyelilerin kabulüne yönelik düşünce ve politika değişikliğinin temelinde birçok farklı sebep bulunmaktadır. Yaşanan 9 yıllık süreç ele alındığında Suriye'de yaşanan çatışmaların bir türlü son bulmaması, bölgede etkisi büyük ülkelerin istikrara yönelik kalıcı bir çözümde anlaşamamaları, ekonomik harcamalar ve ülkemizin içinde bulunduğu ekonomik kriz durumu, Suriyelilerden kaynaklı ileriye dönük sosyal ve demografik kaygılar gibi sebepler Suriye'den gelebilecek yeni göç akınlarına karşı politika deği- 
şikliğinde belirleyici olmaktadır. Tüm bunlar göz önüne alındığında Türkiye'nin ülkeye gelmesi muhtemel yeni göç akınlarına izin vermeyeceği ve Suriye topraklarında bir çözüm bulunarak ülkemizdeki sığınmacıların o bölgelerde hayatlarını devam ettirmesi düşüncesini desteklemeye devam edeceği açıktır.

\section{Sonuç ve Değerlendirme}

Türkiye, yaklaşık 3 milyon 600 bin Suriyeli insanı ağırlamakta ve ülkemizde bulunan Suriyeli insanlara yönelik olumsuz bir tavır içerisinde bulunmamaktadır. Ülkemiz, Suriyeli insanların burada olmalarından çok onları buraya sürükleyen sebeplerin çözüme kavuşmamasından şikâyette bulunmaktadır. Ancak netice olarak sürecin belirsizliğinden dolayı tedbirler almak ve uygulamak mecburiyeti içerisindedir. AB ülkelerinin İdlib konusunda Türkiye'ye gerekli desteği vermemesi ve Türkiye'nin İdlib'deki varlığına ve doğrudan askerlerimize yönelik gerçekleştirilen Rus destekli Esed rejimi hava saldırısı sonrası Suriyeli sığınmacılar konusundaki ilk tavrını kısmen değiştiren Türkiye 28 Şubat 2020 tarihinde akşam saatlerinde tüm sınırlarını açtığını ve ülkeden çıkışta herhangi bir denetim yapılmayacağını bildirmiştir. Bu açıklamanın ardından birçok farklı uyruklu göçmen, sığınmacı, geçici koruma altındaki kişiler özellikle Avrupa sınırımız olan Yunanistan ve Bulgaristan'a geçmek için yola çıkmışlardır. Türkiye' nin sınırlarını gidiş yönüne açmasının ardından 6 Mart 2020 tarihinde İçişleri Bakanı Süleyman Soylu'nun sosyal medya hesabından yaptığı açıklamada 142 bin 175 göçmenin sınırlarımızdan çıkış yaptığını bildirmiştir. Ancak çıkış yapanların tümü Suriyeli değil aynı zamanda diğer ülkelerden de kaçak yollarla gelen insanlarda bulunmaktadır. Türkiye'nin bu tavrı takınmasındaki en büyük etken AB ülkelerinin Suriye konusunda verdiği sözleri tutmaması ve Türkiye'de hükümet tarafından da sıklıkla dile getirilen, $\mathrm{AB}^{\prime}$ nin Türkiye'yi sığınmacıları tutan bir tampon bölge bir duvar olarak görmesinden kaynaklanmaktadır. Ancak Türkiye İdlib konusunda kararlı olduğunu ve destek verilse de verilmese de sahadaki rolünü koruyacağını göstermiştir. Özellikle Türkiye'nin 27 Şubat 2020 tarihinde İdlib bölgesinde rejim ve terör unsurlarına yönelik başlattığ1 Bahar Kalkanı Harekâtı ile bölgede varlığını sürdürmeye devam edeceğini belli etmiştir. Türkiye'nin sınırlarını açmasıyla beraber sığınmacı ve göçmenlerin sınırlarımızdan çıkıp Avrupa'ya geçmeye başlamasının ardından AB ülkelerinin bazıları 
İdlib konusunda Türkiye'nin haklı olduğunu ve Türkiye'nin bu süreçte yanında olunması gerektiğini vurgulamıştır.

Bugünün şartlarında Suriye'de herkes için kalıcı barışçıl bir çözüm bulunmadığı takdirde Türkiye bugüne kadar yapmadığı gibi bundan sonrada taraf olduğu uluslararası göç ve kabul anlaşmaları gereği Suriyeli insanlara yönelik zorla sınır dışı işlemleri yapmayacağı görülmektedir. Ancak bu süreçte uluslararası ilişkilerden kaynaklı sorunlar veya ülke içinde demografik, sosyal ve ekonomik birçok sorunlar ortaya çıktığı takdirde sınır kapılarını açıp isteyen ve gönüllü olanların gitmesine kısmen müsaade edeceği öngörülmektedir. Siyasilerin bugünkü tutumları ele alındığında ise olağandışı durumlar haricinde yeni sığınmacı kabulü de yapılmayacağı açıktır. Ancak Türkiye'nin oluşabilecek yeni göç risklerinde sığınmacılara sırtını döneceği onlara kapılarını kapatacağını düşünmek yanlış bir tutum olacaktır. Türkiye bu süreçte sığınmacıların kabulüne yönelik politikalar değil de oluşabilecek s1ğınmacı göçü riskini ortadan kaldırmaya yönelik Suriye toprakları üzerinde çözüme katkıda bulunma politikası izleyeceğini, bu bağlamda bugüne kadar yaptığı harekâtlar (Zeytin Dalı, Fırat Kalkanı, Bahar Kalkanı, Barış Pınarı) ile sahada olmaya devam edeceğini ve daha fazla Suriyeli insanın yerinden edilmesine engel olacağını göstermiştir. Bu süreçte Suriyeli insanların kendi topraklarında kalabileceği, yerinden edilme tehdidinin olmayacağı bir ortam oluşturmak ve yerinden edilmiş insanlarında Suriye sınırları içerisine dönebilecek terörden arındırılmış güvenli ortamlar oluşturmak Türkiye'nin istediği ve çalışmalarını sürdürdüğü ana politikadır. Türkiye'nin Suriye'de silahlı örgütlerden temizlediği ve yaşanılır kıldığı bölgelere götürdüğü sağlık, eğitim, gida hizmetleri başta olmak üzere tadilat ve yenileme çalışmaları, belediyecilik faaliyetleri gibi pek çok alanda sağladığı hizmetler ile bölgede huzur ve istikrarlı, güvenli bir ekonomik, sosyal yaşam istediği anlaşılmaktadır. 


\title{
EXTENDED ABSTRACT
}

\section{A Research On The Turkey's Attitude Against New Immigration Risks: The Case of Idlib}

\author{
* \\ Yasin Çam - İbrahim Keleş \\ Osmaniye Korkut Ata Üniversitesi - Kocaeli Üniversitesi
}

With the influence of the process called Arab Spring, the actions that started in Syria in 2011 turned into violent clashes over time. Millions of Syrian people have had to migrate abroad due to these armed conflicts and military pressures. The main reason for the process's return to civil war is the inhumane treatment of activists by the Assad regime, the extreme violence and the continued military use of weapons against civilians. (Yllmaz, 2013, s. 2). Turkey has been the first place of escape from the outset for many of the people who have come under pressure as a result of the conflict that began in 2011 and whose presence in Syria poses a vital risk. Although our country population is constantly changing numerically, as of 27 February 2020, it hosts 3 million 587 thousand 266 Syrian refugees. (Göç İdaresi Genel Müdürlüğü, 2020).

Turkey has accepted the Syrian people into the country and has mobilized many opportunities for these people from the very beginning of the process. In this process, Turkey has determined and implemented policies in the field of education, health, harmony and material for people coming from Syria without regard to race, religion or ethnicity. In the 9-year period, Turkey has made many expenditures and suffered negative effects both economically and socially. It is known that the amount of expenditure made by our country for Syrians is 40 billion dollars and it has been expressed from time to time by bureaucrats in the presidency of the Republic of Turkey. Without doubt, Turkey is one of the countries that wants the negative process in Syria to reach a conclusion and to establish a democratic and human rights-respecting state structure. In this context, Turkey, home to approximately 4 million Syrian people for years, has been following the process in Syria closely and has maintained a military presence in some strategically important areas along our country's borders since 2016. Millions of people 
sheltering in this area have been at risk of death since the escalation of attacks in December 2019 on the Syrian city of Idlib, where the Russia-backed Assad regime has carried out occasional attacks. The fact that Idlib is on the border with Turkey and has a $130 \mathrm{~km}$ border with Hatay province has required Turkey to take some precautions against attacks on this region. Turkey is the only escape route for the people trapped in that region because of the attacks. And the prospect of emigrating to Turkey of nearly 4 million Syrian people known to be sheltering in that region will expose our country to a new migration problem. Some academics and bureaucrats have argued that Europe should support Turkey on the issue of Idlib, arguing that not only Turkey but also Europe would be affected by a possible large wave of migration. In this process, which could create a negative situation for Europe. Turkey declared that it could no longer handle the burden of asylum seekers on its own, due to the fact that the EU did not keep its promises on asylum seekers to Turkey and the EU was not on Turkey's side on the Idlib issue. It was reported on 28.02.2020 that it would remove controls at its borders and would not apply any stop policy to asylum seekers and migrants who wish to leave voluntarily. In this context, the Idlib process is important for Turkey, and rather than the previous admission of asylum seekers, a more effective solution was needed within the territory of Syria. Turkey has established sheltering centers for asylum seekers from Syria, providing education and health services, as well as providing many food, clothing and financial assistance. It is also known that the majority of Syrian asylum seekers live outside the sheltering centres, and the same services are provided within these asylum seekers. Turkey, which is known to have spent $\$ 40$ billion financially, is known to have partially changed its policies towards accepting asylum seekers, considering that it is also socially fatigued. One of the reasons for this change is the fact that the EU has not fulfilled some of the conditions of the readmission agreement with the EU and has put Turkey in a difficult position.

Turkey has often expressed the idea of establishing a buffer zone in northern Syria as a measure to prevent terrorist attacks from Syria and eliminate the problem of asylum seekers. Due to the lack of support by the active forces in the region, Turkey has started to create a safe zone by removing terrorist elements along the border with its own military force. As part of the 
operations started in 2016 (Olive Branch, Firat Shield, Spring Shield), Jarablus, Azez, Afrin regions and Tel Abyad and Rasulayn regions were cleared of PYD/YPG and ISIS terrorists and passed under the control of TSK and SMO (Syrian National Army). Syrians have started to return to safe areas that were cleaned within the scope of these operations. A new social order and regional investments has been established byTurkey in the regions where Turkey has cleared from terrorist organizations and the people who returned to these regions began to live in peace. This attitude of Turkey has strengthened its hand to gain support for a self-dominated safe zone policy. As the Assad regime carried out its armed attacks on Idlib in December 2019 and its subsequent attacks on our troops in the region, Turkey has also organised Operation Fountain of Peace to clear this area. Turkey's aim in this operation is to cleanse the region of the Assad regime and the elements that threaten the region, and to restore and secure social order there. An important issue here is to eliminate all the negativity that could cause more asylum seekers to come to our country and ensure that people remain safely on Syrian territory. In this context, it is seen that Turkey is not accepting new migrations, but removing the elements that are causing this migration. There is a change in Turkey's migration policies related to this issue. There are many different reasons behind Turkey's change of policy towards the acceptance of Syrians. Taking into account the 9-year period, the conflict in Syria has never ended, the failure of major countries in the region to agree on a permanent solution to stability, the reasons such as economic spending and the economic crisis situation in our country and the social and demographic concerns arising from the future of Syrians are decisive in the policy change against the new influx of migrants from Syria. Given all this, it is clear that Turkey will not allow any new migratory flows to arrive in the country and will continue to support the idea of finding a solution on Syrian soil so that asylum seekers in our country can continue their lives in those areas.

\section{Kaynakça / References}

Acun, C., ve Salaymeh, B. (2018).. Suriye krizinde yeni safha İdlib. İstanbul: SETA.

Ağır, O., ve Sezik, M. (2015). Suriye'den Türkiye'ye yaşanan göç dalgasından kaynaklanan güvenlik Sorunları. Birey ve Toplum Sosyal Bilimler Dergisi, 5(9), 95-123. 
Aktan, S. (06.09.2019). Cumhurbaşkanı Yardımcısı Oktay: Sinırlarımızı açmak ne bir tehdit ne de blöf. Euronews. 28.03.2020 tarihinde thttps://tr.euronews.com/2019/09/06/fuat-oktay-sinirlarimizi-acmak-ne-bir-tehdit-ne-deblof-ab-suriye-goc-putin-erdogan-g7 adresinden erişildi.

Alptekin, H. (2019). Suriye'de oluşturulacak güvenli bölgede taraflar ve tutumlar. İstanbul: SETA.

Anadolu Ajansı. (05.12.2017). Başbakan yardımcı Akdağ: Suriyeliler için harcanan toplam maliyet 84 milyar 880 milyon lira. Anadolu ajans 14.03.2020 tarihinde aa.com.tr: https:/www.aa.com.tr/tr/ekonomi/basbakan-yardimcisi-akdag-suriyelilericin-harcanan-toplam-maliyet-84-milyar-880-milyon-lira/990509 adresinden erişildi.

Türkiye Suriyelilere Yardım Etme Konusunda Kararlı Adımlar Attı. (24.08.2019). Anadolu Ajansi. 27.02.2020 tarihinde aa.com.tr: https://www.aa.com.tr/tr/turkiye/turkiye-suriyelilere-yardim-etme-konusunda-kararli-adimlaratti/1563713 adresinden erişildi.

10 Soru'da İdlib'de Yaşananlar. (04.02.2020). Anadolu Ajansı. 04.03.2020 tarihinde https://www.aa.com.tr/tr/dunya/10-soruda-idlibde-yasananlar/1723992 adresinden erişildi.

Göçmenler Avrupa Yolunda: Türkiye Kapıları Neden Açt? (04.03.2020). Anadolu Ajansı. 12.03.2020 tarihinde https://www.aa.com.tr/tr/siginmacilar-avrupa-yolunda/gocmenler-avrupa-yolunda-turkiye-kapilari-neden-acti/1754700 adresinden erişildi.

Aslan, M. (2019). Yeniden yapllandrrma Türkiye'nin Suriye'deki modeli. İstanbul: SETA.

Boztepe, M. (13.01.2020). İçişleri Bakanı Soylu: 1 Aralık 2019'dan bu yana İdlib'den 312 bin kişi snırımıza göç etti. Anadolu ajansı. 25.03.2020 tarihinde aa.com.tr: https://www.aa.com.tr/tr/turkiye/icisleri-bakani-soylu-1-aralik-2019dan-buyana-idlibden-312-bin-kisi-sinirimiza-goc-etti/1700986 adresinden erişildi.

Bakan Akar: Yeni bir göç dalgasının önlenmesi için gayret gösteriyoruz. (31.05.2019). CNNTürk. 25.03.2020 tarihinde cnnturk.com: https://www.cnnturk.com/turkiye/bakan-akar-yeni-bir-goc-dalgasinin-onlenmesi-icin-gayret-gosteriyoruz adresinden erişildi.

Devran, Y., ve Özcan, Ö. F. (2016). Söylemlerin dilinden Suriye Sorunu. Marmara Illetişim Dergisi, 25, 35-52.

Eliaçı, Z. (04.03.2020). 5. Soru: Mülteci krizi ve Türkiye. 30.03 .2020 tarihinde setav.org: https://www.setav.org/5-soru-multeci-krizi-ve-turkiye/ adresinden erişildi. 
Fırat, H. (15.01.2019). Güvenli bölgeye Ankara'nın Şartı 08.03.2020 tarihinde https:/www.hurriyet.com.tr/yazarlar/hande-firat/guvenli-bolgeye-ankaranin-sarti-41083066 adresinden erişildi.

Göç İdaresi Genel Müdürlüğü. (27.02.2020). Geçici koruma. 04.03. 2020 tarihinde goc.gov.tr: https://www.goc.gov.tr/gecici-koruma5638 adresinden erişildi.

Göç İdaresi Genel Müdürlüğü. (05.03.2020). Geçici koruma. 12.03.2020 tarihinde goc.gov.tr: https://www.goc.gov.tr/gecici-koruma5638 adresinden erişildi.

İdlib'den Göç Dalgası. (20.12.2019). HaberTürk. 27.02.2020 tarihinde haberturk.com: https:/www.haberturk.com/idlib-den-goc-dalgasi-2551570 adresinden erişildi.

Erdoğan Suriyeli sığınmacılara seslendi. (08.10.2014). Hürriyet. 28.03.2020 tarihinde hurriyet.com.tr: https:/www.hurriyet.com.tr/gundem/erdogan-suriyeli-siginmacilara-seslendi-27342780 adresinden erişildi.

Cumhurbaskani Erdogan Turkiye Suriye Kaynakli Yeni Bir Goc Dalgasini Kaldiramaz (22.12.2019). İhlas Haber Ajanst. 15.03.2020 tarihinde iha.com.tr: https://www.iha.com.tr/haber-cumhurbaskani-erdogan-turkiye-suriye-kaynakli-yeni-bir-goc-dalgasini-kaldiramaz-818784/ adresinden erişildi.

Koyuncu, A. (2015). Yerel halkın "açık kapı" politikası ve Suriyelilere İlişkin kanaatleri. Disiplinlerarası Göç ve Göç Politikaları Sempozyumu İstanbul: İstanbul Sebahattin Zaim Üniversitesi Sosyal Hizmet Bölümü. 455-477.

Köker, İ. (23.10.2019). Soçi Mutabakatı: Erdoğan ve Putin, 3 yılda kaç kere görüştü, Suriye konusunda ne kararlar alındı? 31.03 .2020 tarihinde bbc.com: https://www.bbc.com/turkce/haberler-dunya-42323920 adresinden erişildi.

Özdemir, Ö. B. (02.11.2017). Türkiye' nin İdlib'deki varlığı ve olası engeller. 29.03 .2020 tarihinde http://www.suriyegundemi.com/2017/11/02/turkiyenin-idlibdeki-varligi-ve-olasi-engeller/ adresinden erişildi.

Öztürk, S., ve Çoltu, S. (2018). Suriyeli mültecilerin Türkiye ekonomisine etkileri. Balkan Sosyal Bilimler Dergisi, 7(13), 188-198.

Stratejikortak. (04.04.2018). Dünden bugüne tüm Suriye Zirveleri (Kronolojik). 15.03.2020 tarihinde https://www.stratejikortak.com/2018/04/suriye-zirve-astana-cenevresoci.html adresinden erişildi.

T.C. Dışişleri Bakanlığı. (16.03.2020). Türkiye-Suriye siyasi ilişkileri. 16.03 .2020 tarihinde http://www.mfa.gov.tr/turkiye-suriye-siyasi-iliskileri-.tr.mfa adresinden erişildi.

İdlib'in stratejik önemi. (28.02.2020). TRT Haber. 10.03.2020 tarihinde trthaber.com: https:/www.trthaber.com/haber/gundem/idlibin-stratejik-onemi463732.html adresinden erişildi. 
İdlib'in Stratejik Önemi. (28.02.2020). TRT Haber. 05.03.2020 tarihinde trthaber.com: https:/www.trthaber.com/haber/gundem/idlibin-stratejik-onemi463732.html adresinden erişildi.

Yılmaz, H. (2013). Türkiye'de Suriyeli mülteciler-İstanbul Örneği- tespitler, ihtiyaçlar ve öneriler. İstanbul: Mazlumder.

\section{Kaynakça Bilgisi / Citation Information}

Çam, Y. ve Keleş, İ. (2020). Türkiye'nin yeni göç risklerine karşı tutumu üzerine bir inceleme: İdlib örneği. OPUS-Uluslararası Toplum Araştırmaları Dergisi, 16(Eğitim ve Toplum Özel Sayısı), 6392-6412. DOI: $10.26466 /$ opus.719410 